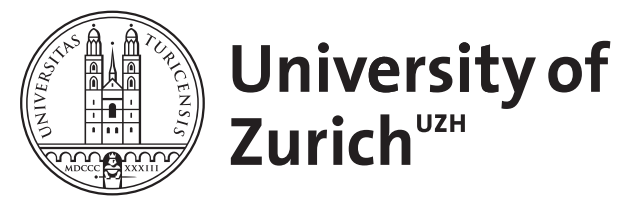

\title{
A new lamniform shark Protolamna ricaurtensis sp. nov. from the Lower Cretaceous of Colombia
}

\author{
Carrillo-Briceño, Jorge D ; Parra, Juan D ; Luque, Javier
}

\begin{abstract}
The Lower Cretaceous record of lamniforms from South America is scarce and poorly known, containing only two reports of isolated teeth from the upper Hauterivian of Argentina and the Albian of Peru. Here, we describe a partial articulated tooth set referable to †Protolamna ricaurtensis sp. nov. from the upper Barremian-lower Aptian deposits of the Paja Formation (Andes of Colombia). The new species corresponds to one of the oldest fossil lamniforms to date reported from South America. This articulated tooth set is the only known for the family †Pseudoscapanorhynchidae, and possibly the oldest in its type for a lamniform from the Lower Cretaceous. Our findings offer new insights in to the lamniform paleodiversity of the northwestern margin of Gondwana during the Lower Cretaceous. Keywords Mesozoic Barremian Aptian Elasmobranchii South America Andes
\end{abstract}

DOI: https://doi.org/10.1016/j.cretres.2018.12.007

Posted at the Zurich Open Repository and Archive, University of Zurich ZORA URL: https://doi.org/10.5167/uzh-159565

Journal Article

Accepted Version

Originally published at:

Carrillo-Briceño, Jorge D; Parra, Juan D; Luque, Javier (2019). A new lamniform shark Protolamna ricaurtensis sp. nov. from the Lower Cretaceous of Colombia. Cretaceous research, 95:336-340.

DOI: https://doi.org/10.1016/j.cretres.2018.12.007 


\section{Accepted Manuscript}

A new lamniform shark Protolamna ricaurtensis sp. nov. from the Lower Cretaceous of Colombia

Jorge D. Carrillo-Briceño, Juan Parra, Javier Luque

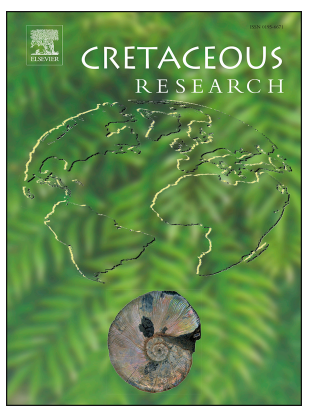

PII:

S0195-6671(18)30362-8

DOI:

https://doi.org/10.1016/j.cretres.2018.12.007

Reference: YCRES 4037

To appear in: Cretaceous Research

Received Date: 5 September 2018

Revised Date: 13 November 2018

Accepted Date: 10 December 2018

Please cite this article as: Carrillo-Briceño, J.D., Parra, J., Luque, J., A new lamniform shark Protolamna ricaurtensis sp. nov. from the Lower Cretaceous of Colombia, Cretaceous Research, https:// doi.org/10.1016/j.cretres.2018.12.007.

This is a PDF file of an unedited manuscript that has been accepted for publication. As a service to our customers we are providing this early version of the manuscript. The manuscript will undergo copyediting, typesetting, and review of the resulting proof before it is published in its final form. Please note that during the production process errors may be discovered which could affect the content, and all legal disclaimers that apply to the journal pertain. 
2 A new lamniform shark Protolamna ricaurtensis sp. nov. from the Lower

\section{Cretaceous of Colombia}

4

5

6

7

*Correspondence to: jorge.carrillo@ pim.uzh.ch ; jorgedcb100@ gmail.com

\section{Abstract}

The Lower Cretaceous record of lamniforms from South America is scarce and poorly known, containing only two reports of isolated teeth from the upper Hauterivian of Argentina and the Albian of Peru. Here, we describe a partial articulated tooth set referable to †Protolamna ricaurtensis sp. nov. from the upper Barremian-lower Aptian deposits of the Paja Formation (Andes of Colombia). The new species corresponds to one of the oldest fossil lamniforms to date reported from South America. This articulated tooth set is the only known for the family $\dagger$ Pseudoscapanorhynchidae, and possibly the oldest in its type for a lamniform from the Lower Cretaceous. Our findings offer new insights in to the lamniform paleodiversity of the northwestern margin of Gondwana during the Lower Cretaceous. 
Keywords: Mesozoic; Barremian; Aptian; Elasmobranchii; South America; Andes.

\section{Introduction}

Lamniformes, also known as mackerel sharks, is a clade of marine selachians represented

today by ten genera and fifteen species (Weigmann, 2016), including the great white, and sand tiger sharks, among others. The earliest known lamniform fossil extends back to the Lower Cretaceous (Kriwet et al., 2008; Schmitz et al., 2010), with a greater diversity of forms occurring during the Upper Cretaceous-Paleogene interval in numerous localities worldwide (Guinot and Cavin, 2016; Cappetta 2012). Overall, the Cretaceous record of lamniform sharks is well known, mostly from the Northern Hemisphere (e.g., Europe and North America, see Cappetta 2012), as these regions have been extensively studied since the 19th century. On the contrary, the fossil record of lamniform sharks in South America is represented exclusively by isolated dental elements of at least nine genera from the Upper Cretaceous of Argentina (Arratia and Cione, 1996; Bogan and Agnolin, 2010; Prámparo et al., 2013; Schroeter et al., 2014), Brazil (Maury, 1930; Oliveira, 1954; Rebouças and Silva Santos, 1956), Chile (Otero et al., 2013) and Venezuela (Moody and Maisey, 1994; Carrillo-Briceño et al., 2008; Guinot and Carrillo-Briceño 2018). Only few Lower Cretaceous records of lamniforms are known, such as $†$ Priscusurus adruptodontus Kriwet, 2006, from the middle? Albian of Peru, and $\dagger$ Protolamna sp. from the upper Hauterivian of Argentina (Gouiric-Cavalli et al., 2018). A detailed discussion about the taxonomic status of $\uparrow P$. adruptodontus was presented by Guinot and Carrillo-Briceño (2018).

The fossil record of Cretaceous chondrichthyans from northern South America is poorly known with only few remains of lamniforms and ptychodonts from Colombia (Reinhart, 1951; Brito and Janvier, 2002; Carrillo-Briceño et al., 2016) and Venezuela (Moody and 
Maisey, 1994; Carrillo-Briceño, 2009, 2012; Carrillo-Briceño et al., 2008; Carrillo-Briceño and Lucas, 2013; Guinot and Carrillo-Briceño 2018). Here we describe a piece of an articulated tooth set of $\dagger$ Protolamna ricaurtensis sp. nov., from the Lower Cretaceous of the Andes of Colombia. The new fossil represents one of the oldest fossil lamniforms species to date reported from South America, and shed new light on the Lamniform paleodiversity of the northwestern margin of Gondwana during the Early Cretaceous.

\section{Materials and methods}

The partial articulated tooth set described here is included in a single block of indurated limestone matrix from the Lower Cretaceous Arcillolitas Abigarradas Member of the Paja Formation (upper Barremian-lower Aptian), cropping out in the Loma La Catalina locality $\left(05^{\circ} 38^{\prime} 00^{\prime \prime} \mathrm{N}\right.$ and $073^{\circ} 34^{\prime} 40^{\prime \prime} \mathrm{W}$; 2139 m.a.s.l), located $6 \mathrm{~km}$ east of the town of Villa de Leyva, Department of Boyacá, Colombian Andes Eastern Cordillera (Fig. 1). The Paja Formation is thought to have been deposited in shallow marine waters with restricted circulation (Etayo-Serna, 1968). Etayo-Serna (1968) divided the Paja Formation into three members: the "Lutitas Negras Inferiores" (Lower Paja Formation), "Arcillolitas Abigarradas" (Middle Paja Formation), and the "Arcillolitas con Nódulos Huecos" (Upper Paja Formation). The outcrops of the Loma La Catalina locality (La Catalina hill) belong to the middle segment of the Paja Formation, which were recognized by Etayo-Serna 1968 as the "Arcillolitas Abigarradas" Member (see Hoedemaeker, 2004, fig. 2; Hampe, 2005, fig. 1). This member is 480 m thick (Etayo-Serna, 1968). An upper Barremian-lower Aptian age has been suggested for this member based on the recognition of the $†$ Pseudocrioceras ammonite assemblage zone (Hoedemaeker, 2004). The specimen referred here was discovered and collected by one of the authors (J.P.), and is housed in the Centro de Investigaciones Paleontológicas (CIP), Villa de Leyva, Colombia, under the acronym FCG-CBP-93. To date there is no a stratigraphic 
75 column of the Loma La Catalina outcrops (“Arcillolitas Abigarradas” Member), which

76 preclude an accurate localization of fossiliferous levels where the specimen FCG-CBP-93 was

77 collected. Taxonomic identification was based on an extensive bibliographical review, and the

78 systematic classification follows Cappetta (2012).

79

80

\section{Systematic description}

Class Chondrichthyes Huxley, 1880

Subclass Elasmobranchii Bonaparte, 1838

Order Lamniformes Berg, 1958

Family $†$ Pseudoscapanorhynchidae Herman, 1979

Genus †Protolamna Cappetta, 1980

$\dagger$ Protolamna ricaurtensis sp. nov.

\section{(Fig. 2)}

Derivation of name. The species is named in honour of Antonio Ricaurte (1797-†1814), the Villa de Leyva town's most famous son, who was a patriot officer during the independence war, becoming a hero and martyr during the Battle of San Mateo (Venezuela), immolating himself exploding an arsenal, and preventing it from falling into enemy hands. This action is immortalized in the Colombian national anthem: "Ricaurte en San Mateo, en átomos volando" (Ricaurte in San Mateo, in atoms flying).

\section{Holotype. FCG-CBP-93}

Referred material. The specimen FCG-CBP-93 corresponds to a partial, articulated tooth set of a left upper jaw containing at least 29 teeth. 
Type locality. Limestone layers of the "Arcillolitas Abigarradas" Member (Paja Formation, upper Barremian-lower Aptian) cropping out in the Loma La Catalina locality.

Diagnosis. Species characterized by the following features: 1) teeth characterized by a triangular, thick, and short mainly cusp, 2) proportionally smaller bulky lateral cusplets and 3) a massive root with a prominent and bulky lingual protuberance.

Description. At least 29 teeth can be observed in the tooth set, of which only 13 are complete, while the rest are represented by crown and root fragments. Five tooth rows (teeth arranged mesiodistally and parallel to the jaw edge) and at least seven tooth files (series of teeth perpendicular to the jaw edge, sensu Cappetta, 2012) in lingual view are identified (Fig. 2 AD). Most of the tooth files are laterals, with the most distal tooth file presumably being a posterior one. The arrangement pattern suggests that there are no definite signs of overlap between root lobes of successive tooth files within a tooth row. Tooth measurements of the most complete and visible teeth, range between 10.9 and $18.4 \mathrm{~mm}$ in height and between 6.5 and $10.9 \mathrm{~mm}$ in width. During preparation, two teeth were removed from the tooth set (Fig. 2 E-J), allowing a detailed study of the lingual and labial side of the specimens. Complete teeth are characterized by a slightly inclined, triangular, thick, and short main cusp with smooth cutting edges. A single pair of lateral, bulky, triangular cusplets are widely separated and inclined slightly towards a more labial position than the main cusp. The labial face of the main cusp is nearly flat, forming a typical, distinctly concave crown-root boundary. Vertical and parallel enameloid folds are present, extending from the base almost to the apex. These folds can also be observed in the labial side of the lateral cusplets. The lingual face of the main cusp is convex and forms vertical and parallel folds, extending from the base up to less than the middle part of the cusp. At the base of the cusp, a well-developed lingual neck is noted. The root is high (at least half as high as the complete tooth), and is characterized by long subparallel lobes and a prominent and bulky lingual protuberance. No nutrient grooves 
can be observed at the center of the lingual protuberance, but more or less large central foramina can be observed in the well-preserved specimens.

\section{Discussion}

The genus $\dagger$ Protolamna is probably one of the most ancient lamniforms (Rees, 2005; Kriwet et al., 2008; Cappetta, 2012), with a chronostratigraphic distribution ranging from the Valanginian (Early Cretaceous) to the Maastrichtian (Late Cretaceous). The fossil record of $\dagger$ Protolamna includes Africa, Asia, Australia, Europa and North and South America (e.g., Cappetta, 2012; Gouiric-Cavalli et al., 2018). †Protolamna was originally described on the basis of isolated teeth from the upper Aptian of France (†Protolamna sokolovi Cappetta, 1980), and a detailed discussion about the taxonomic status of the genus is presented by Schmitz et al. (2010). To date, at least seven nominal species from the Lower and Upper Cretaceous are recognized. Lower Cretaceous species include $\dagger$ Protolamna infracretacea (Leriche, 1910) (Hauterivian), †Protolamna sarstedtensis Schmitz, Thies and Kriwet, 2010 (Lower Barremian), and $\dagger P$. sokolovi (upper Aptian) from European basins, and $\dagger$ Protolamna roanokeensis Cappetta and Case, 1999, from the Albian of North America. Upper Cretaceous species include $\dagger$ Protolamna acuta Müller and Diedrich, 1991, and $\dagger$ Protolamna carteri Cappetta and Case, 1999, from the Cenomanian, of Europe and North American, and $\dagger$ Protolamna borodini Cappetta and Case, 1975, from the Maastrichtian of North America and Campanian of Europe (Siverson 1992; Vullo, 2005). Other records referring material from the Lower and Upper Cretaceous to †Protolamna sp. can be found in Rees (2005), Cappetta (2012), Vullo and Courville (2014) and Gouiric-Cavalli et al. (2018).

The combination of different morphological characters as a triangular, thick, and short main cusp with and proportionally smaller bulky lateral cusplets, and a massive root with a 
prominent and bulky lingual protuberance (Fig. 2 E-J), allows to clearly differentiate $\dagger$ Protolamna ricaurtensis sp. nov. from species like $\dagger P$. sokolovi, $\dagger P$. infracretacea, $\dagger P$. sarstedtensis, $\dagger P$. acuta and $\dagger P$. borodini. The closest dental morphology to $\dagger P$. ricaurtensis sp. nov. is that of $\dagger P$. roanokeensis from the Albian of North America (see Welton and Farish, 1993, p. 110, figs. 1-9, p. 111, figs. 1-2; Cappetta and Case, 1999, fig. 8). $\dagger$ Protolamna roanokeensis can be distinguished from other species of the genus by the distinctive larger teeth, which bear a triangular main cusp with well-developed vertical and parallel enameloid folds in both lingual and labial faces, and their wider and divergent lateral triangular cusplets (Cappetta and Case, 1999). According to Cook et al. (2008), the teeth of $\dagger P$. roanokeensis resemble closely those of $\dagger P$. carteri, but the latter is smaller and has a larger lingual protuberance with a distinctive groove, and exhibits a completely smooth labial face of the main cusp, and slender lateral cusplets (Cappetta and Case, 1999; Cook et al., 2008). Its morphology contrasts also with those of $\dagger P$. ricaurtensis sp. nov. The upper Barremian-lower Aptian $† P$. ricaurtensis sp. nov. differs from the Albian $\dagger P$. roanokeensis in exhibiting proportionally smaller bulky lateral cusplets and a more massive, and thicker root with a prominent and bulky lingual protuberance.

$\dagger$ Protolamna species are known only from isolated teeth (Leriche, 1910; Cappetta and Case, 1975, 1999; Cappetta, 1980; Müller and Diedrich, 1991; Schmitz et al. 2010). Using the "artificial" tooth-set of $\uparrow P$. roanokeensis illustrated by Welton and Farish (1993) as a reference, it is possible to identify the tooth set of $†$ Protolamna ricaurtensis sp. nov. holotype as a portion of a left upper jaw dentition. Although the holotype is not complete, since it preserves only a reduced portion of the lateral part of a left upper jaw, its teeth arrangement pattern seems to be similar to those found in both extinct and recent lamniforms (e.g. Shimada, 1997, 2002; Vullo et al., 2016). This specimen represents the only articulated fossil 
tooth set known for the $†$ Pseudoscapanorhynchidae family, and possibly the oldest of its type for a lamniform from the Lower Cretaceous.

The teeth of $\dagger$ Protolamna have a typical morphology characterized by a slender central cusp with vertical striations and large lateral cusplets. These are characteristics of clutching/tearing-type teeth, and suggest that species of this genus fed on small prey (Tomita, 2011). The Arcillolitas Abigarradas Member, from where the studied material comes, is interpreted to have been deposited in a complex shallow marine environment with restricted circulation (Etayo-Serna, 1968), where invertebrates, fishes and marine reptile remains are common (e.g., Páramo, 2015), indicating the presence of abundant resources. Although it is difficult to infer the ecological role played by †Protolamna ricaurtensis sp. nov., the information available indicates that it probably was a small nectobenthic shark, occupying a low trophic position, feeding on small fishes and cephalopods (see Tomita, 2011).

\section{Concluding Remarks}

The tooth set of $\dagger$ Protolamna ricaurtensis sp. nov. represents the only articulated fossil tooth set for the $\dagger$ Pseudoscapanorhynchidae family known to date. The presence of this new species in the Barremian-Aptian of Colombia corresponds to one of the oldest fossil lamniforms to date reported from South America. Although the fossil record of fishes for the region is scarce, our findings shed new light on the chondrichthyan diversity and paleobiogeographic patterns in northwestern Gondwana during the Lower Cretaceous.

\section{Acknowledgements}


192 Our deepest thanks to Mary Luz Parra-Ruge (CIP), and Dirley Cortés (CIP, Smithsonian

193 Tropical Research Institute), for providing field and lab assistance. To Marcelo Sánchez-

194 Villagra for generous and significant counseling and collaboration, to Thodoris Argyriou for

195 suggestions and comments to improve the manuscript, and to Freddy Parra (CIP) for help

196 preparing the specimen. The Editor, Soledad Gouiric Cavalli, and an anonymous reviewer are

197 thanked for their valuable comments and suggestions on the manuscript.

\section{References}

Arratia, G., Cione, A.L., 1996. The fish fossil record of southern South America. Münchener

Geowissenschaftliche Abhandlungen 30, 9-72.

Berg, L.S., 1958. System der rezenten und fossilen Fischartigen und Fische. Deutscher Verlag

Wissenschaft, Berlin, 310 pp.

Bogan, S., Agnolin, F.L., 2010. Primera ictiofauna marina del Cretácico Superior (Formación

Jaguel, Maastrichtiano) de la provincia de Río Negro, Argentina. Papéis Avulsos de Zoologia

(São Paulo) 50, 175-188. DOI: http://dx.doi.org/10.1590/S0031-10492010001200001.

207 Bonaparte, C.L., 1838. Selachorum tabula analytica. Nuovi Annali della Science Naturali

Bologna 1, 195-214.

Brito, P.M., Janvier, P., 2002. A ptychodontid (Chondrichthyes, Elasmobranchii) from the

Upper Cretaceous of South America. Geodiversitas 24(4), 785-790.

211 Cappetta, H., 1980. Modification du statut générique de quelques espèces de sélaciens 212 crétacés et tertiaires. Palaeovertebrata 10, 29-42. 
213 Cappetta, H., 2012. Chondrichthyes. Mesozoic and Cenozoic Elasmobranchii: Teeth.

214 Handbook of Paleoichthyology, 3E. Verlag Dr. Friedrich Pfeil, Munich, 512 p.

215 Cappetta, H., Case, G.R., 1975. Contribution à l'étude des Sélaciens du groupe Monmouth 216 (Campanien-Maestrichtien) du New Jersey. Palaeontographica, Abt. 151, 1-46.

217 Cappetta, H., Case, G.R., 1999. Additions aux faunes de sélaciens du Crétacé du Texas 218 (Albien supérieur-Campanien). PalaeoIchthyologica 9, 5-111.

219 Carrillo-Briceño J.D., 2009. Presencia del genero Ptychodus (Elasmobranchii: 220 Ptychodontiade) en el Cretácico Superior de los Andes de Trujillo Venezuela. Geominas 37, $221 \quad 207-210$.

222 Carrillo-Briceño J.D., 2012. Presencia de Ptychodus mortoni (Elasmobranchii: 223 Ptychodontidae) en el Cretácico Superior de Venezuela. Revista Geológica de América 224 Central 46,145-150. DOI: https://doi.org/10.15517/rgac.v0i46.1837.

225 Carrillo-Briceño, J.D., Spencer, L.G., 2013. The first tooth set of Ptychodus atcoensis 226 (Elasmobranchii: Ptychodontidae), from the Cretaceous of Venezuela. Swiss Journal of 227 Paleontology 132, 69-75. DOI: https://doi.org/10.1007/s13358-013-0053-3.

228 Carrillo-Briceño, J.D., Ayala, R., Chávez-Aponte, E.O., González-Barba, G., 2008. Registro 229 de Serratolamna serrata (Elasmobranchii: Serratolamnidae) en el Cretácico Superior 230 (Maestrichtiense) de los Andes Venezolanos. Geominas 36 (47), 160-163.

231 Carrillo-Briceño, J.D., Cadena, E.A., Dececchi, A.T., Larson, H.C.E., Du, T.Y., 2016. First 232 record of a hybodont shark (Chondrichthyes: Hybodontiformes) from the Lower Cretaceous 233 of Colombia. Neotropical Biodiversity 2(1), 81-86. 
Cook, T.D., Wilson, M.V.H., Murray, A.M., 2008. A middle Cenomanian euselachian assemblage from the Dunvegan Formation of northwestern Alberta. Canadian Journal of Earth Sciences 45(10), 1185-1197. DOI: https://doi.org/10.1139/E08-064.

Cope E.D., 1875. The vertebrata of the Cretaceous formations of the West. Report of the United States Geological Survey of the Territories 2, 1-302.

Etayo-Serna, F., 1968. El Sistema Cretáceo en la región de Villa de Leiva y zonas próximas. Geología Colombiana 5, 5-74.

241 Gouiric-Cavalli, S., Cione, A.L., Lazo, D.G., Cataldo, C.S., Aguirre-Urreta, M.B., 2018. First 242 record of elasmobranchs from the Lower Cretaceous of Argentina (Neuquén Basin).

243 Cretaceous Research 81, 1-8. DOI: https://doi.org/10.1016/j.cretres.2017.09.003

244 Guinot, G., Cavin, L., 2016. 'Fish' (Actinopterygii and Elasmobranchii) diversification 245 patterns through deep time. Biological Reviews 91(4), 950-981. DOI: https://doi.org/10.1111/brv.12203.

247 Guinot, G., Carrillo-Briceño, J.D., 2018. Lamniform sharks from the Cenomanian (Upper 248 Cretaceous) of Venezuela. Cretaceous Research 82, 1-20. DOI: 249 https://doi.org/10.1016/j.cretres.2017.09.021.

250 Hampe, O., 2005. Considerations on a Brachauchenius skeleton (Pliosauroidea) from the lower Paja Formation (late Barremian) of Villa de Leyva area (Colombia). Fossil Record 8(1), 37-51. DOI: https://doi.org/10.1002/mmng.200410003.

Herman J. 1979. Réflexions sur la systématique des Galeoidei et sur les affinités du genre les Sables du Kattendijk à Kallo (Pliocène inférieur, Belgique). Annales de la Société 256 géologique de Belgique 102, 357-377. 
257 Hoedemaeker, P.J., 2004. On the Barremian-lower Albian stratigraphy of Colombia. Scripta

258 Geologica 128, 3-15.

259 Huxley, T. H., 1880. On the application of the laws of evolution to the arrangement of the

260 Vertebrata, and more particularly of the Mammalia. Proceedings of the Zoological Society of 261 London 43, 649-662.

262 Kriwet, J., 2006. Biology and dental morphology of Priscurus adruptodontus, gen. et sp. nov.

263 (Chondrychthyes, Lamniformes) from the Albian (Early Cretaceous) of Peru. Journal of 264

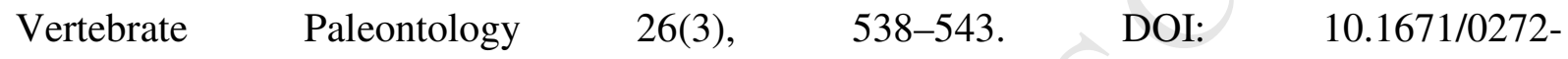
265 4634(2006)26[538:BADMOP]2.0.CO;2.

Kriwet, J., Klug, S., Canudo, J. I., Cuenca-Bescos, G., 2008. A new Early Cretaceous lamniform shark (Chondrichthyes, Neoselachii). Zoological Journal of the Linnean Society 154(2), 278-290. DOI: https://doi.org/10.1111/j.1096-3642.2008.00410.x.

Moody, J.M., Maisey, J.G., 1994. New Cretaceous marine vertebrate assemblages from north-western Venezuela and their significance. Journal of Vertebrate Paleontology 14(1), 1- 
279 Oliveira, P.E., 1954. Fósseis da camada de fosfato de Olinda, Estado de Pernambuco. Anais 280 da Academia Brasileira de Ciências 26(2), 12-13.

281 Otero, R.A., Oyarzún, J.L., Soto-Acuña, S., Yury-Yáñez, R.E., Gutierrez, N.M., Le Roux, 282 J.P., Torres, T., Hervé, F., 2013. Neoselachians and Chimaeriformes (Chondrichthyes) from 283 the latest Cretaceous-Paleogene of Sierra Baguales, southernmost Chile. Chronostratigraphic, 284 paleobiogeographic and paleoenvironmental implications. Journal of South American Earth 285 Sciences 48, 13-30. DOI: https://doi.org/10.1016/j.jsames.2013.07.013.

Páramo-Fonseca, M.E., 2015. Estado actual del conocimiento de los reptiles marinos 15(1), 40-57. DOI: http://dx.doi.org/10.5710/PEAPA.12.06.2015.98.

Prámparo, M.B., Cione, A.L., Gonzalez Riga, B., 2014. Sharks (Neoselachii) and palynomorphs from Mendoza (Argentina): new evidence of the Late Cretaceous Atlantic

DOI: https://doi.org/10.1080/03115518.2014.849027.

Rebouças, J.C., Silva Santos, R., 1956. Fauna ictiológica do fosfato de Pernambuco, Brasil. Boletim da Divisão de Geologia e Mineralogia, siver no. 162, 1-29. Wąwał, central Poland. Palaeontology 48(2), 209 - 221. DOI: https://doi.org/10.1111/j.14754983.2005.00441.x.

Reinhart, R.H., 1951. A new shark of the family Ptychodontidae from South America. 
Schroeter, E.R., Egerton, V.M., Ibiricu, L.M., Lacovara, K.J., 2014. Lamniform shark teeth from the Late Cretaceous of southernmost South America (Santa Cruz Province, Argentina). PLoS One 9(8), e104800. DOI: https://doi.org/10.1371/journal.pone.0104800.

Schmitz, L., Thies, D., Kriwet, J., 2010. Two new lamniform sharks (Leptostyrax stychi sp. nov. and Protolamna sarstedtensis sp. nov.) from the Early Cretaceous of NW Germany. Neues Jahrbuch für Geologie und Paläontologie, Abhandlungen 257(3), 283-296. DOI: 10.1127/0077-7749/2010/0074.

Siverson, M., 1992. Biology, dental morphology and taxonomy of lamniform sharks from the Campanian of the Kristianstad Basin, Sweden. Palaeontology 35(3), 519-554.

Tomita, T., 2011. Mouth-Size Estimation of a Primitive Lamniform Shark, Protolamna: low trophic position in Lamniform shark origin. Paleontological Research 15(2) 68-76. DOI: https://doi.org/10.2517/1342-8144-15.2.068.

Vullo, R., 2005. Selachians from the type Campanian area (Late Cretaceous), Charentes, western France. Cretaceous Research 26(4), 609-632. doi.org/10.1016/j.cretres.2005.03.006

Vullo, R., Courville, P., 2014. Fish remains (Elasmobranchii, Actinopterygii) from the Late Cretaceous of the Benue Trough, Nigeria. Journal of African Earth Sciences 97, 194-206. https://doi.org/10.1016/j.jafrearsci.2014.04.016

Weigmann, S., 2016. Annotated checklist of the living sharks, batoids and chimaeras (Chondrichthyes) of the world, with a focus on biogeographical diversity. Journal of Fish Biology 88(3), 837-1037. DOI: https://doi.org/10.1111/jfb.12874.

Welton, B.J., Farish, R.F., 1993. The Collector's Guide to Fossil Sharks and Rays from the Cretaceous of Texas, Lewisville, Texas, Before Time, 204 p. 


\section{$325 \quad$ Figure captions}

Figure 1. Geographical location map and generalized geology and stratigraphy of the Villa 329 the Leyva area (after Etayo-Serna, 1968; Hampe, 2005). Abbreviations: Fm. Formation; CIP. 330 Centro de Investigaciones Paleontológicas, Villa de Leyva.

Figure 2. $†$ Protolamna ricaurtensis sp. nov. (FCG-CBP-93) from the upper Barremian-lower Aptian deposits of the Paja Formation near Villa de Leyva, Boyacá, Colombia. A-C, partial 334 articulated tooth set in different views. D, tooth set highlighting complete (green) and 335 incomplete (red) teeth, as well as the removed tooth. E-J, complete removed teeth. Views: 336 labial (F, J), lingual (E, I), profile $(\mathrm{G}-\mathrm{H})$. 

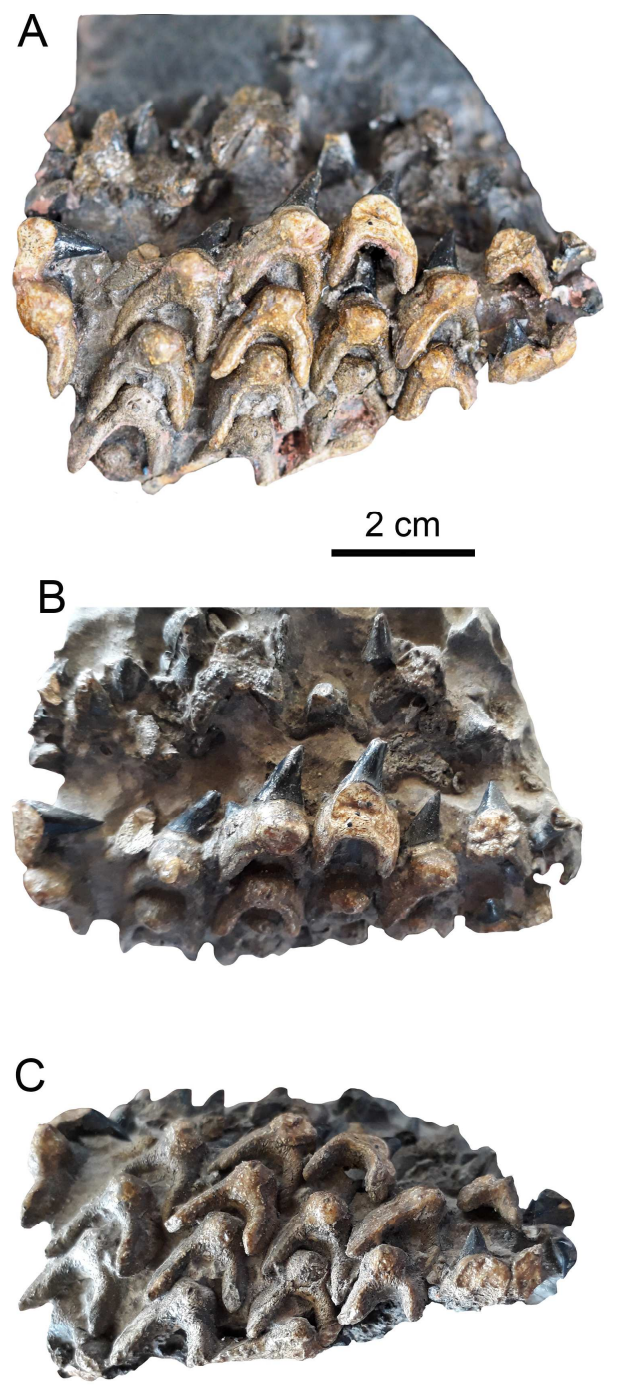
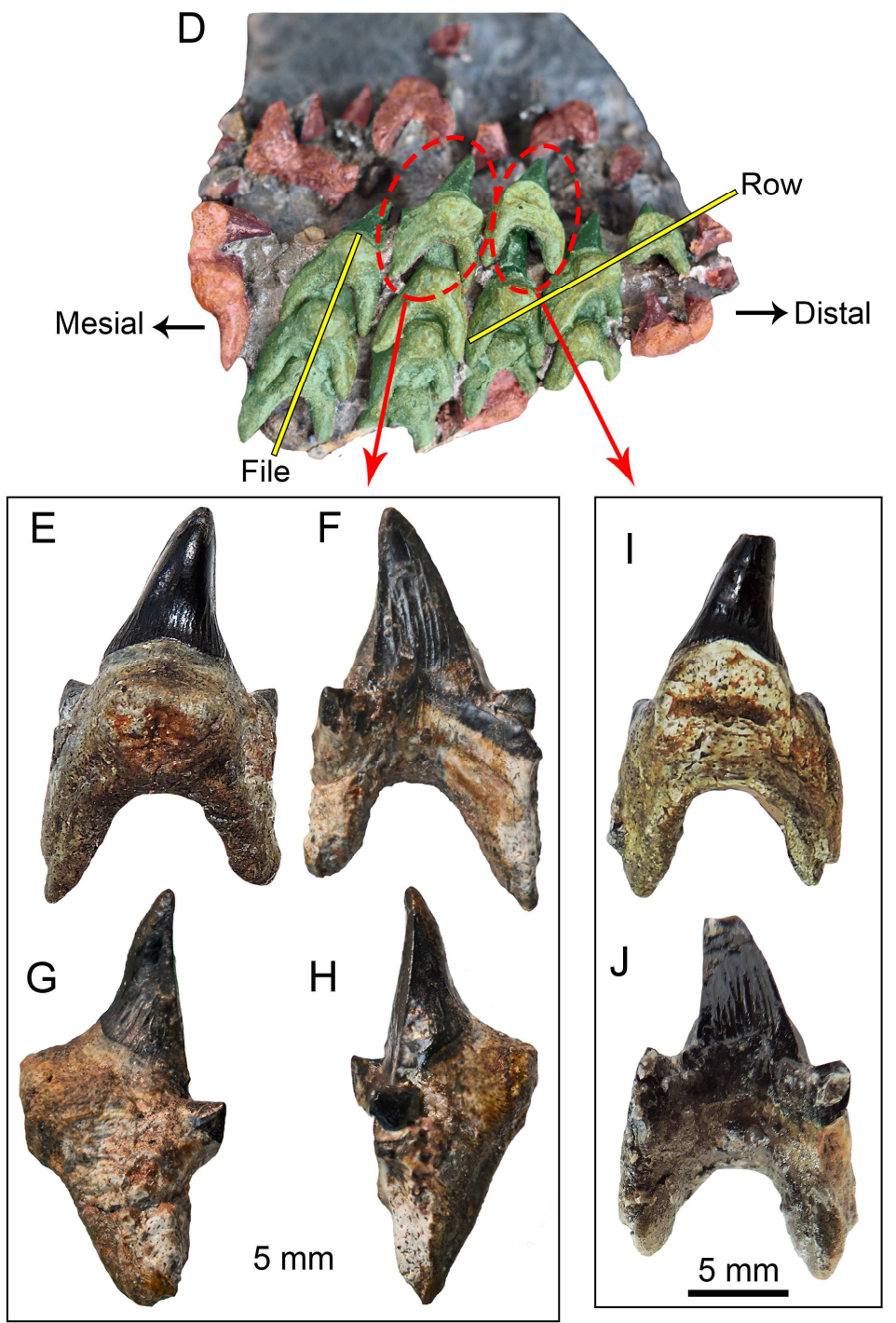

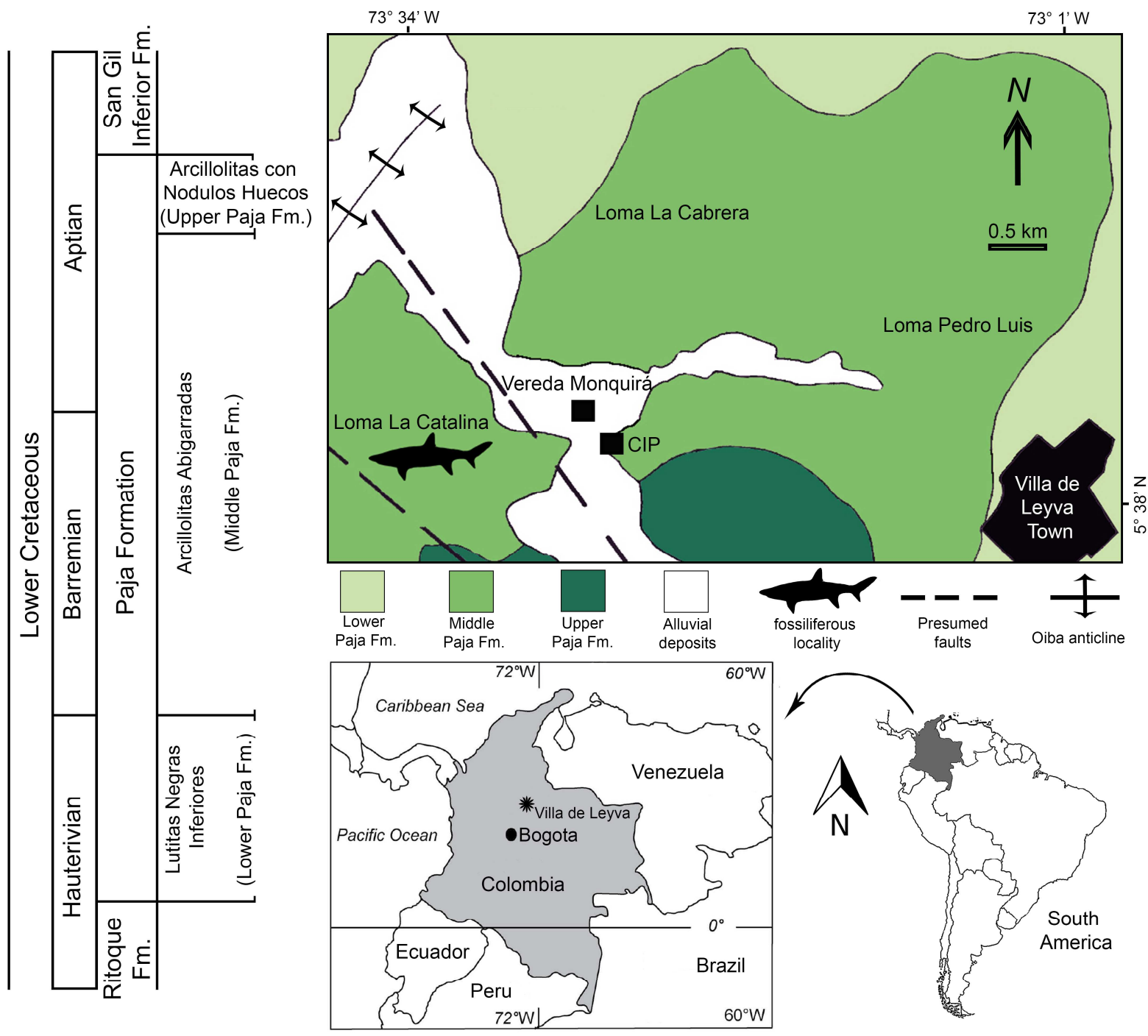